\title{
BUSH FIRES IN VICTORIA
}

$\mathrm{T}$ HE drought of the early summer, which affected all south and south-eastern Australia, was followed by a heat wave in the first fortnight of January which reached sufficient intensity to reduce leaf litter in the forest to tinder dryness. The usual firing by cattle graziers had been in progress for some months over all the rough mountain grazing land which lies to the north of the prime forest belt. Northern and north-western winds of great force set in during the first week of January and fanned the sporadic fires into conflagrations which swept the country wherever forest existed and also much of the cleared grass lands where the stock had left enough herbage to carry a fire.

Forest losses were severe in New South Wales, and in the Australian capital territory 3,600 acres were burnt; this represents a quarter of its plantation area. South Australia suffered also, but pro. portionately less, for her plantations are not exposed to the same external fire hazard. Tasmania escaped at the time that the fires were at their worst on the mainland, but towards the end of January and early February, serious fires broke out in that State and severe losses were sustained.

The greatest losses occurred in Victoria, where by the end of that first fortnight of January $5,038,600$ acres of forest were burnt over, sixty-seven saw mills and approximately six hundred houses and cottages were destroyed and seventy-one persons lost their lives. The full extent of the loss in timber cannot be gauged, but the amount in the easily accessible areas has been assessed, and this reaches the alarming total of $2,070,000,000$ superficial feet in the round. It is estimated that $916,000,000$ superficial feet of this killed timber can be salvaged. The dead timber in less accessible areas of burnt ash and alpine ash forest cannot be salvaged.

Victoria's loss amounts to a national disaster, for the chairman of the Forests Commission, speaking at a representative meeting of timber men last year, stated that supplies of ash timber would last less than twenty years.

It will be seen that already the overcutting of the forests had brought the industry to the point where future supplies of logs were becoming a very serious matter, and now the greater part of the timber has been destroyed by fire. Victoria's loss is so severe that it is difficult to see how the industry can fail to sink into insignificance once the salvaged timber has been converted. Investigations are now being made to see whether it is

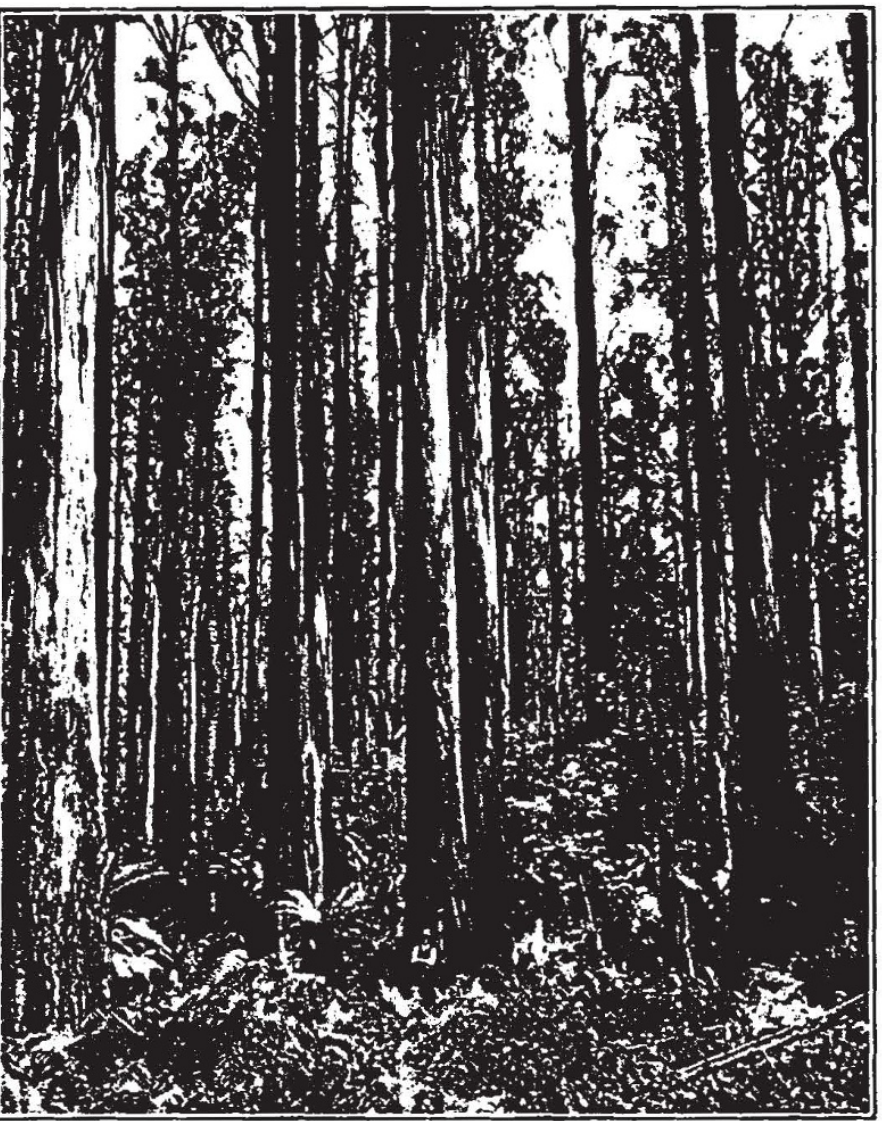

Fig. 1.

[Photo: Forests Commission
VIRGIN MOUNTAIN ASH FOREST, CUMBBELAND VALLEY, Victoria.

possible to prolong the period of utilizing burnt logs. It is a question of preventing fungus attack, and is therefore a difficult matter.

The genus Eucalyptus-the gum tree-of which all the burnt forests consist, is in the majority of cases difficult to kill outright. After a very severe fire has passed through, burning all the crowns, epicormic branches spring from branch and bole and restore the leaf area, and so life is maintained and the greedy branches on the limbs grow into mature branches, new crowns are formed and the greedy branches on the boles fall off. A month after such a fire as has been experienced, the bush 


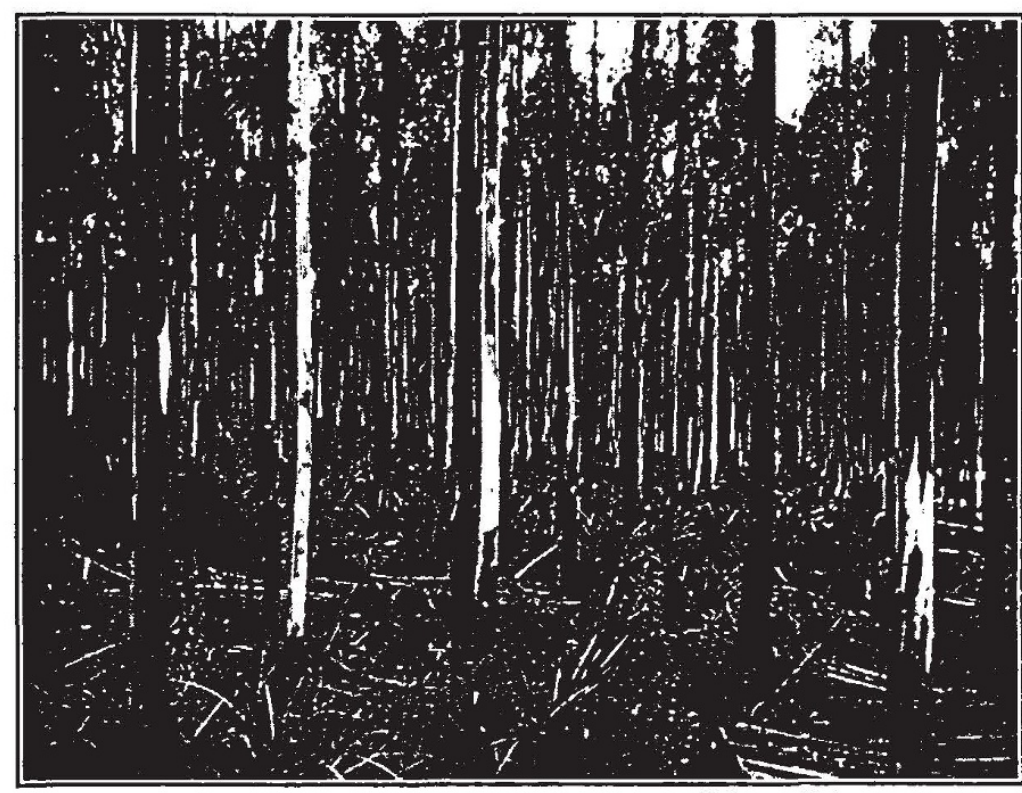

Fig. 2.

Natural regeneratiox of asi at Noodjee, Victorla, following THE 1926 FIRE.

is sprouting with. green tufts of leaves exceptand this is what makes Victoria's case so seriousthe species composing the forest belonging to the ash group of gum trees. These are Eucalyptus regnans, mountain ash, and Eucalyptus gigantea, alpine ash; there are three others, but they are not of the same milling value. These ashes do not renew their leaf surface by means of epicormics and so are killed outright by any fire which attains such an intensity as to burn the crowns. A great part of the Victorian forests consists of these ashes, and the bulk of the sawn timber of that State is ash. Fig. 1 shows a type of forest of moun. tain ash before the fire. The trees attain heights of more than three hundred feet, and the volume per acre on first quality sites is only beaten by such forests as virgin Douglas fir. So while in the coastal regions of New South Wales great conflagrations took place at the same time as the ash forests were being destroyed in Victoria, the trees will recover, and though greatly injured and yielding as they will inferior products, will reform a forest and perpetuate it.

In the ash belts of Victoria the only hope is that sufficient seed will

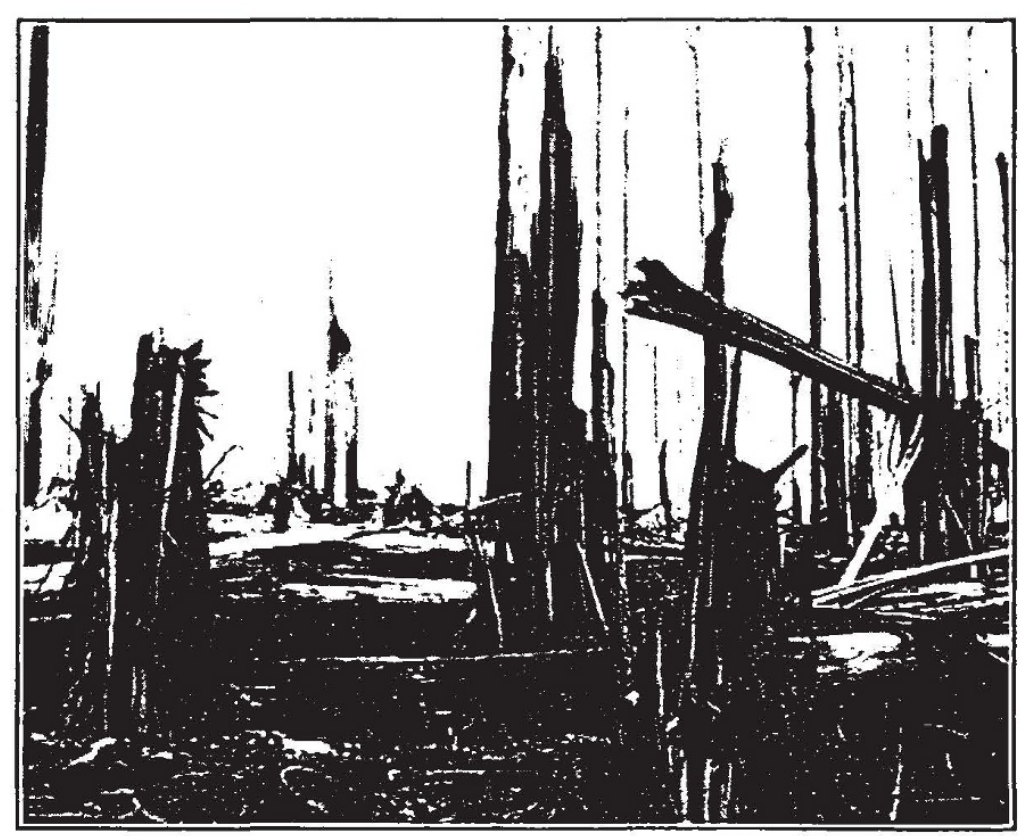

Fig. 3 .

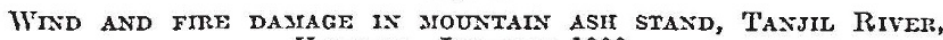
Victoria, JaNUARY 1939. 
has occurred in many parts of Victoria, including the fine regrowth shown in the picture. What happens then is complete destruction, for the young trees forming the regrowth are too young to bear seed and there are no old seed trees to help, and so the forest becomes bracken land, which can only be reforested by planting - a very expensive business at Australian rates of wages.

Fig. 3 shows the effect of fire on good regrowth. The Forests Commission has been engaged in tending those fine areas of regrowth and in protecting

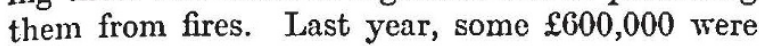
spent by the Commission on such work, and fires have wiped out the greater part of the asset. Nuch of the money has gone into roads and permanent improvements of a capital nature and their value will remain if the forests are regrown and protected from fire.

This brings up the question: Are these fires inevitable? If the answer is yes, then to spend more money on forestry in Victoria is not justified. There is no doubt that periods of intense dryness, accompanied by high winds, recur at comparatively short intervals. They vary in degree, but too much credence should not be given to the statements that have been published that January 1939 was the worst ever experienced since white settlement of Victoria. Well-cquipped meteorological stations are still uncommon in the country districts, and the evidence of old inhabitants is notoriously unreliable in all matters; degrees of heat and strength of wind are not phenomena capable of easy estimate. Probability points to intense fire conditions having occurred many times and likely to recur at least five times in the rotation of an ash forest.

This being so, how is it that there are any ash forests at all ? The tree is killed by a severe fire and the regrowth can scarcely escape destruction with such a periodicity of five years. The fact that virgin forests existed up to the recent fire in Yictoria is evidence that catastrophic fires did not occur before white settlement. The trees of the virgin forest are far older than the settlement of Australia, and apart from this evidence there are several facts which make it quite certain that the black man's fires were of small nature. The late Sir Baldwin Spencer, discussing this matter with the writer, said that the aboriginal only burnt to provide fresh grass to attract kangaroo and wallaby and, owing to his primitive weapons, his aim was to burn very small areas which the clan could surround when the marsupials were feeding. It is probable that no fires were lit for this purpose in the virgin ash forest because to start a fire in such forests would be difficult and the results would not be so successful for the aboriginals as in the grassed savannah forests adjoining.
It is clear that fires have increased in intensity since white men began to develop Victoria. The early history is interesting in this regard, for it shows what difficulties were encountered by the settlers who were given country to open in the ash belt. They found it most difficult to get a 'good burn' after they had felled the timber. It was only when many holes had been carved out of the forest and a very dry period occurred that a sufficient 'face' of fire was established to sweep through the green forest.

It was not until 1851 that a great conflagration was lighted, and this was so unusual and the results so devastating, that it is known to-day as "Black Thursday, the Day of Terror". Since then, fires of great intensity have occurred at intervals which have become shorter.

The great fires run as follows: 1851, 1898, 1926, 1932 , 1939, and of these, the last was only the most serious because of the greater loss of life owing to the country being more opened up and, in consequence, more peopled. The evidence is quite clear that the effect of settlement has been to increase the fire hazard enormously and that forests which were once practically immune from fire became first vulnerable as the face of the conflagration increased and were finally burnt through. The opening up of virgin forest by logging operations contributed largely to the vulnerability of the forests, and the fire prevention organization of the Forests Commission, while adequate to deal with all fires that broke out within the forest reserves, found itself impotent against the raging fires which swept in from Crown lands outside.

After the disasters of 1926 and 1932, fire legislation was tightened up, and to-day the fire prevention laws of Victoria are sufficiently stringent, if enforced, to make fire setting a very risky business in any accessible part of the forests.

The education of the public has been developed to an extent which ensures that everyone is warned against the careless use of fires. The meteorological service sends out through the broadeasting network warnings when the temperature and evapora. tion are reaching dangerous levels. Roads, tracks and breaks have been cut through the forest and aerial patrols report the outbreak of any fire. Every year by notice in the Victorian Government Gazette all areas of land subject to fire hazard are proclaimed as coming under the bush fire laws. These areas cover all Victoria except the inland Mallee country. All these laws and precautions and all this propaganda did not save the position in January. The Government appointed a Royal Commission to inquire into the causes and effects of that fire and to recommend remedies; its report is not yet published so the matter is still sub judice. Comment must, therefore, be restricted. 
It is quite clear that no internal organization within forest areas can prevent a repetition of the disaster of January 1939. The only way to prevent it is to give the Forestry Commission of Victoria, not only the legal power, but also the departmental machinery and equipment to control fires in the open Crown land leased to graziers beyond the boundaries of the forest reserves. How wide a protection belt is needed must depend on the topography. Where a range of mountains occurs in the Crown land, then it must be included if it is twenty miles away, for it has been definitely established that fires are started on plains 3,000 feet below by bark and debris blown from trees burning on a range twenty miles away. The wind reaches hurricane force, and even on the plains it reached 40-50 m.p.h. at the height of the fire on January 14 . Where the forest reserve is surrounded by plain country, the protective belt may be safely made narrow. Everywhere throughout the protection belt roads must be made and look-out towers erected. Instant detection is the first step, and then immediate suppression. Wireless is a valuable aid to both these services, making communication possible between the towers, the fire suppression gang and with headquarters. All this is going to cost a great deal of money, the failure to provide which in the past is the main reason for the disaster. Conflagrations are not inevitable; the forest departments of Australia have shown this in the case of fires starting within their forests, and all that is necessary is to extend the foresters' jurisdiction and operations to cover the land held under grazing occupancy outside.

The tragic loss of life has brought the question of safety measures very much into the foreground. Dug-outs proved very valuable to forest mill-hands and others during the last outbreak and many lives were saved through them.

\title{
REACTIONS WITH MONOLAYERS AND THEIR BIOLOGICAL ANALOGIES
}

\author{
By Prof. Eric K. Rideal, M.B.E., F.R.S., and Dr. J. H. Schulman, \\ Department of Colloid Science, Cambridge
}

$\mathrm{T}$ HE film technique permits us not only to examine the progress of chemical and enzyme reactions in monolayers but also to investigate mixed films, for example, lipo proteins, and the effects of injecting various reactants beneath monolayers. It has been found that the reactions of monolayers of lipoids such as cholesterol with substances injected into the substrate are dependent both on the nature of the polar group and on that of the hydrocarbon 'tail' of the injected reactant. Similar conclusions can be drawn as to the extent of reaction with monolayers of proteins. The possibilities in this case are somewhat more complex, for the protein monolayer must be regarded as a triplex system, the extended polypeptide chains separating an upper hydrophobic layer from a lower hydrophilic one, the latter containing the polar groups of the side chains of the protein.

It is possible to separate the various factors which govern the adsorption by, or the penetration into, a monolayer of such a structure. These naturally include not only the usual criteria of water and oil solubility but also more specific terms, such as the interaction of polar groups and special steric configurations which permit of adlineation of specific hydrophobic portions of the molecules. We include also not only the effects produced by changing the number and spacing of polar groups in the reacting molecule, that is, multiple point contact, but also the structure of the hydrophobic portions which may or may not be conducive to close packing of the reactant in a sheet below the protein monolayer.

We have examined inter alia a number of œstrogenic compounds ${ }^{2}$ of which the $p \cdot p^{\prime}$-dihydroxy diphenyl hexadiene and stilbene derivatives form a definite series in which the ratio of hydrophobic to hydrophilic portion could be varied. These show marked differences in cestrogenic activity with a sharp maximum at $p \cdot p^{\prime}$-dihydroxy diphenyl hexadiene and $p \cdot p^{\prime}$-dihydroxy diethyl stilbene or dibenzyl. The cestrogenic activity falls some thirty to fifty-fold on increasing or decreasing the number of $\mathrm{CH}_{2}$ groups in the molecule by two.

In the accompanying figure are shown the extents of interaction as measured by the change in surface potential with a gliadin monolayer on a substrate buffered at $p \mathrm{H} 8$ on injection of $3 \mathrm{mgm} . / 100$ c.c. of reactant into the substrate. The ostrogenic activities of the various compounds are likewise included. It will be noted that reaction sets in rapidly, but equilibrium is only finally attained after some 15-20 minutes, and 